\title{
Un logos des-autorizado en el escenario de la Atenas democrática (y en Wikipedia)
}

\author{
An Unauthorized Logos on the Stage of Democratic Athens (and on Wikipedia) \\ Ana Iriarte Goñi* \\ Universidad del Pais Vasco, España \\ ana.iriarte@ehu.eus
}

\section{Resumen:}

Este artículo contempla la mítica figura de Casandra, hija del rey oriental Príamo y portavoz desautorizada de Apolo, en el episodio de su biografía que la sitúa en el saqueo de Troya, violada por el aqueo Áyax ante el altar de Atenea. Dicho episodio se comenta al mismo tiempo desde la tradición iconográfica y desde la tradición literaria griegas. Dos tipos de fuentes muy diferentes que coinciden a la hora de atribuir a la joven una valentía propia de hoplitas.

Palabras clave: Casandra, Áyax, Violación, Políxena, Hécuba, Tradición iconográfica y literaria griega.

\section{Abstract:}

This essay deals with the mythical figure of Cassandra, daughter of the western king Priam and unauthorized spokesperson on behalf of Apollo, in the episode of her biography that places her in the plundering of Troy, raped by the Achaean Ajax before Athena's altar. Said episode is tackled from the perspective of both iconographic and literary Greek traditions, two very different sources which coincide in attributing the young woman the braveness typical of the hoplites.

KEYWORDS: Cassandra, Ajax, Rape, Polyxena, Hecuba, Iconographic and literary Greek traditions.

El ser de palabra imagina su muerte, y esa muerte, que precisamente por ser imaginada nada tiene que ver con lo absoluto de la misma (imaginar la muerte propia equivale a intentar ese imposible que sería ser testigo de la propia ausencia).

(Gómez Pin, 2012)

Las siguientes páginas se centran en una figura de la mitología y de la tradición literaria griegas muy conocida, aunque no en toda su complejidad: ${ }^{1}$ Casandra, hija del rey oriental Príamo y profetisa de Apolo. Una heroína, en la que se articulan aspectos clave de la reflexión desarrollada por la civilización de los antiguos griegos en torno a las identidades humana y sobrehumana. Con tal fin, me basaré, alternativamente, en fuentes escritas de época clásica y en el discurso iconográfico, en el que destaco desde ahora una imagen que será clave en el recorrido. Se trata del episodio de la biografía de Casandra que la sitúa en el saqueo de Troya, en el momento en que se enfrenta -con el valor de un guerrero, como pretendo demostrar- a la violación del griego Áyax, la cual transcurre, precisamente, ante el altar de la protectora de las vírgenes que es la diosa Atenea. Así plasmó el episodio el pintor Cleófrades en el año 480 a. C. (el año, recordémoslo para situarnos en el contexto histórico al que nos referimos, de la Victoria de Salamina). 


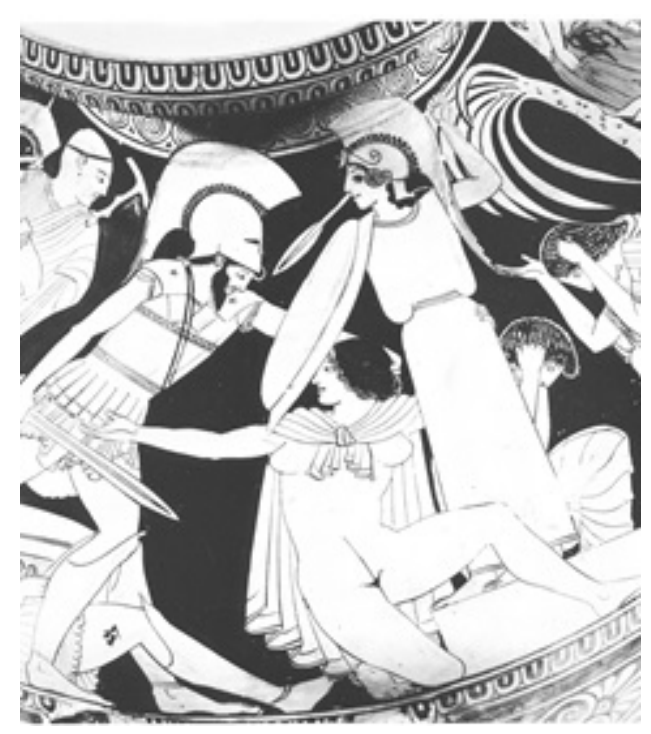

Como guías de nuestra ronda, elegimos, pues, imágenes y textos procedentes, sobre todo, de la antigüedad griega, pero también de épocas más cercanas a nuestros días. Como prueba de esto último, recordaremos la descripción canónica de la figura de Casandra, hija de Príamo de Troya, que facilita el imprescindible Diccionario de la Mitología griega y romana, publicado por Pierre Grimal en 1951 e incesantemente reeditado:

Casandra había recibido el don profético del propio Apolo. El dios, enamorado de ella, le había prometido enseñarle a adivinar el porvenir si accedía a entregarse a él. Casandra aceptó el pacto, pero, una vez instruida, rehusó. Entonces Apolo le escupió en la boca, retirándole no el don de profecía, pero sí el de la persuasión.

Generalmente, se considera a Casandra como una profetisa "inspirada", igual que la Pitia o la Sibila. El dios tomaba posesión de ella y, en pleno delirio, ella formulaba los oráculos. (Grimal, 2004, p. 89)

Quisiera, no obstante, incidir en un dato esencial para la asociación que plantea Grimal, basada en fuentes literarias griegas en lo que se refiere al carácter "delirante" de ambas profetisas, a saber, que la palabra de la Pitia de Delfos está garantizada por la institución délfica, mientras que la voz de Casandra no cuenta con la “autorización” del dios responsable de la profecía verbal que triunfó en la Atenas clásica.

La confrontación entre dos imágenes refleja bien esta diferencia. En primer lugar, observamos la imagen de un vaso ático de figuras rojas (440-430) en la que el rey de Atenas, Egeo, se somete, paciente, a la consulta oracular protagonizada por la Pitia para saber el origen de la esterilidad que sufre. Se trata de la única representación de la Pitia perteneciente a la época dorada ateniense. En ella, la portavoz oficial de Apolo está serenamente apoyada sobre el trípode y con una rama de laurel en la mano derecha, es decir, asociada a los dos símbolos por excelencia de dicho dios en tanto que patrono de la profecía. 


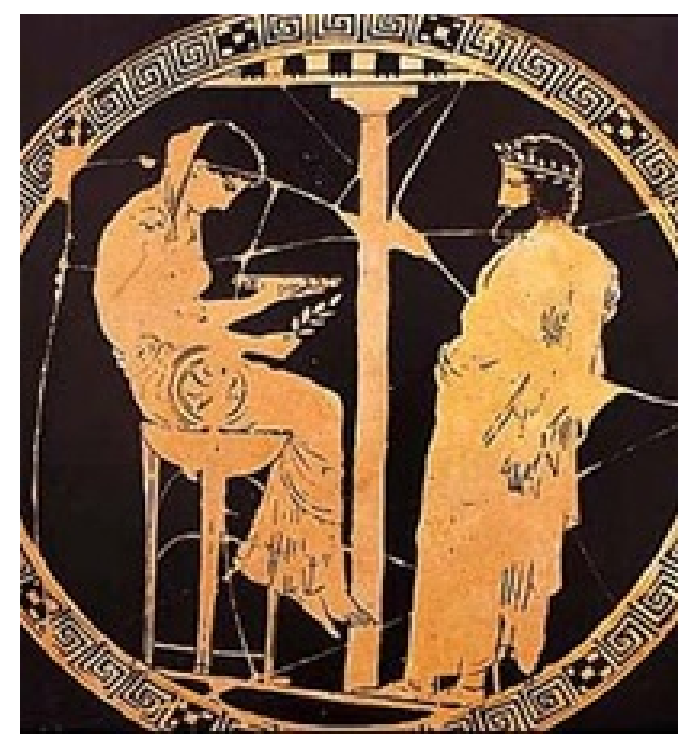

Tras el vaso ático de la Pitia, contemplaremos la gema de época de Augusto que muestra a Casandra, también profeta de Apolo, pero sentada sobre una roca, como expulsada del trípode-trono apolíneo, el cual se localiza, vacío, del lado derecho de la imagen. En cuanto a la postura de la profeta o profetisa, muy inclinada hacia adelante y con el rostro entre las manos, muestra la desesperación que le produce el no ser autorizada por Apolo para llegar a persuadir a su entorno de las verdades que ella sabe y con las que quisiera prevenir a los demás. ${ }^{2}$

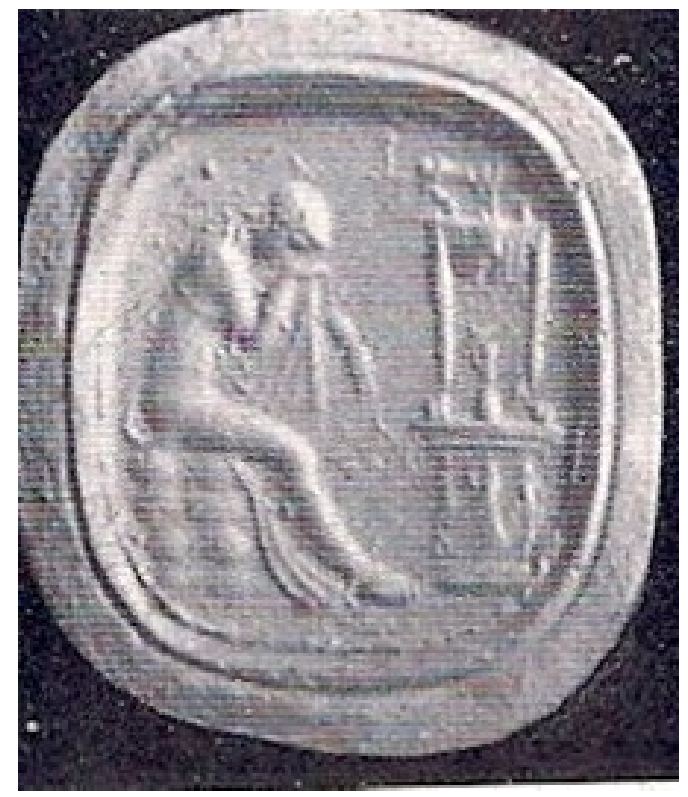

La lucidez desesperada de Casandra, más o menos contenida, será un motivo tentador para los artistas a lo largo de la tradición occidental. Así, el simbolista alemán Max Klinger (1857-1920), esculpe un busto que acentúa artísticamente el poder de la mirada de nuestra profeta mediante la cornalina que da forma a sus ojos evocando las visiones que la abrasan, según Esquilo, como el propio fuego. ${ }^{3}$ 


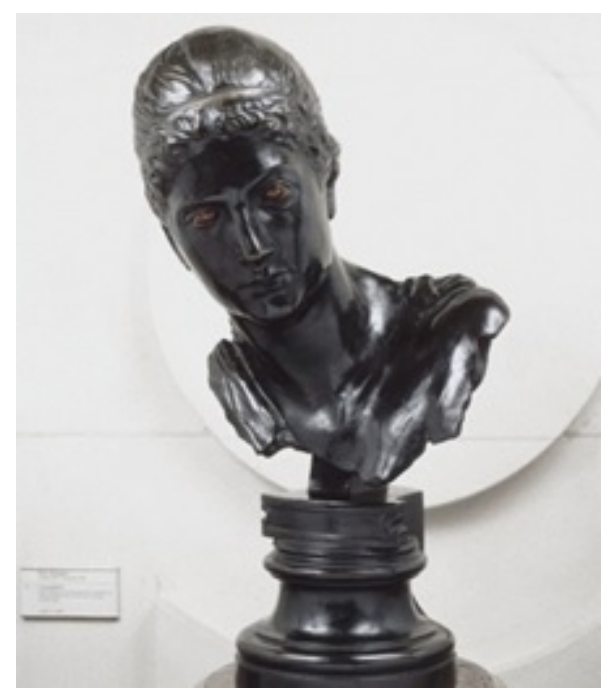

Como ejemplo segundo de la condición de vidente exaltada de la hija de Príamo, disfrutaremos el logro pictórico del prerrafaelista Frederick Sandys (1864), el cual retoma, consciente o inconscientemente, motivos de la iconografía antigua como el de la muralla, símbolo del conjunto de la pólis, de la sociedad a la que la lúcida Casandra, con la mirada y la boca artísticamente desencajadas, no consigue avisar del peligro.

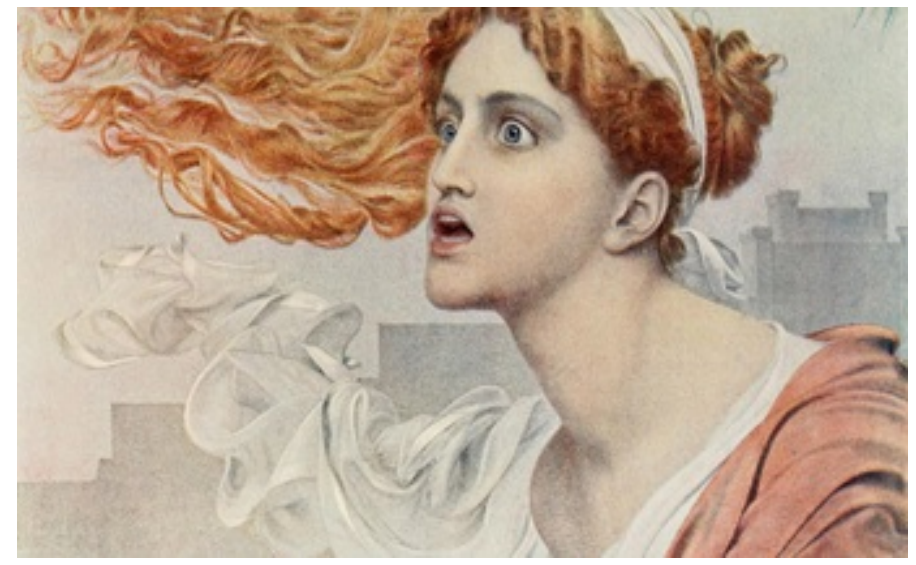

"Con su cabellera ondeando al viento, Casandra, hija de Príamo, rey de Troya, advirtió a su padre de la desastrosa guerra que se avecinaba, pero nadie le hizo caso". Tal es la imagen literaria de Casandra que Doris Lessing (Premio Nobel y, en cierta manera, Casandra contemporánea) recrea en su libro El viento se llevará nuestras palabras (2002, pp. 21-22).Un trabajo firmado en 1987, en el que la profeta griega es invocada para simbolizar las desatendidas señales de alerta que anunciaban la destrucción de Afganistán, acaecida casi una década más tarde.Y es que Casandra, además de profetisa, es un ser plenamente identificado con la guerra.

\section{VOCES FEMENINAS EN TIEMPOS DE GUERRA}

Como es sabido, la tradición homérica cuenta que la Guerra de Troya se extendió durante diez años y culminó con una cruel victoria griega. La ciudad oriental fue incendiada y saqueada por estos últimos. Los troyanos asesinados. Las troyanas esclavizadas.

En el prólogo de Troyanas de Eurípides, el terrible escenario del día después del saqueo es descrito por Posidón, divinidad del mar y constructor junto a Apolo de las "murallas de pulidas piedras" que hicieron de 
Troya una ciudad invencible, hasta que Ulises puso en práctica la artimaña de introducir en ella un inmenso caballo de madera rebosante de lanceros.

Posidón se despide de la ciudad en la que ya no recibirá más sacrificios, horrorizado por los gritos de las únicas supervivientes: las cautivas que están siendo sorteadas entre los griegos. En cuanto a las mujeres de palacio, reservadas para los jefes del ejército vencedor, esperan recluidas (en un campamento) en torno a la reina-madre, Hécuba, cuyo desconsuelo es resumido por el propio dios en los siguientes términos: ${ }^{4}$

Si alguien quiere ver a la desdichada Hécuba, aquí la tiene, postrada ante las puertas, derramando abundante llanto por numerosas razones: su hija Políxena ha muerto valientemente [tlemónos] ante la tumba de Aquiles; muertos son Príamo y sus hijos, y a Casandra, a quien el soberano Apolo dejó soltera y entregó al delirio profético, la desposará Agamenón en unión secreta, despreciando las leyes divinas y toda religión. (Eurípides, Troyanas 36-44)

Políxena y Casandra. Dos doncellas educadas para casarse con amables príncipes orientales, a las que Posidón distingue entre las numerosas hijas de Hécuba, asociándolas al padre y a los varones muertos por la patria. En adelante, iremos viendo lo coherentes que resultan las palabras de Posidón desde las particulares coordenadas del pensamiento griego.

En tanto que víctimas de los Aqueos, Casandra y Políxena se asemejan extraordinariamente. En esta ocasión, nos centraremos particularmente en Casandra, quien dispone de tradiciones literarias y artísticas mucho más enriquecidas debido, ante todo, a su carrera de profetisa incomprendida. La figura de Políxena nos servirá para tener claro que el heroísmo que se le reconoce a Casandra no es una excepción en el pensamiento griego.

\section{LA PRINCESA VIOLADA: DE LA DESNUDEZ HEROICA A LA DESNUDEZ ERÓTICA}

Volviendo a la despedida del divino protector de Troya que fue Posidón, cabe detenerse en una de las atrocidades que este resalta: una violación perpetrada, precisamente, en el templo de la protectora de la virginidad. La propia Atenea, defensora hasta ese momento de los griegos, va en busca de su rival Posidón para comentarle el ultraje que ella y el sagrado espacio de su templo han sufrido "cuando el griego Áyax atrajo hacia sí [condujo, heîlke] a Casandra por la fuerza" (Troyanas 70).

"Atraer hacía sí violentamente", "conducir a la fuerza": uno de los eufemismos usados por los antiguos griegos para aludir a la violación, conocida también como “rapto”. Pero sigamos prestando atención a la queja de la diosa: "Y los aqueos no lo han castigado, ni siquiera se lo han reprochado. (...) He decidido que el retorno de los griegos sea amargo" (Troyanas 71-75).

Dos pinturas modernas evocan el brutal comportamiento de Áyax. La primera de ellas, la barroca de Antoine Rivalz (finales XVII-inicios XVIII), Ajax arrastra por los pelos a Casandra fuera del templo de Atenea. 


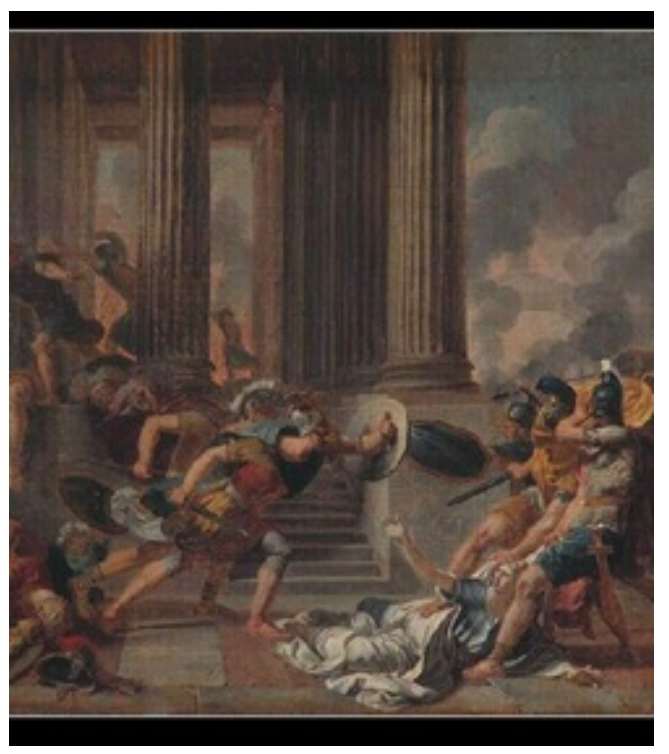

Una segunda representación moderna del "rapto" de Casandra despierta nuestra curiosidad, la del pintor neoclásico Jerôme Martin Langlois (1810), cuyo estilo evoca los grandes retablos de Louis David, y en la que creemos percibir al tiempo a Casandra reclamando venganza en el altar de Atenea y, al fondo, el propio acto de la violación.

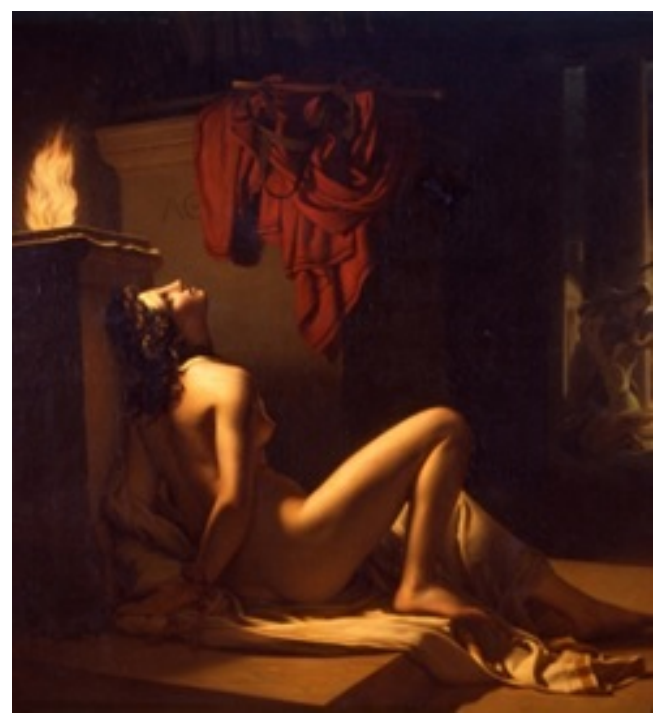

La violación de Casandra viene a situarse en el origen del infernal retorno que tuvieron los griegos, en especial Ulises, el artífice de la toma de Troya. Pues la hija predilecta de Zeus contó con la complicidad de este y de su tío Posidón para que lluvia, truenos, oleaje y remolinos vapulearan las naves de los perversos ganadores. Así de relevante es para Eurípides, el primero de los crímenes cometidos por los griegos contra la sabia princesa Casandra.

Es importante mostrar que la violación de Casandra fue atendida por la iconografía antigua, narrada en imágenes, antes de convertirse en paradigma de crueldad bélica en la tradición literaria que conocemos. En dicha tradición, el acto pervertido de Áyax se evoca mediante la desnudez, parcial o total, de la profetisa.

Esta es la razón que nos lleva a considerar una norma básica del arte griego de épocas arcaica y clásica: que en dicho arte la yuxtaposición vestido/desnudo funciona como un discriminador de primera línea en la particular construcción helena de las identidades femenina y masculina. ${ }^{5}$ 
La imaginería griega (de forma exactamente opuesta a la nuestra) tiende a cubrir el cuerpo femenino: ya sea como muestra de pudor, en el caso de las mujeres honestas, ya sea para realzar la belleza, ocultándola al menos parcialmente, en el caso de las servidoras de Afrodita y de la propia diosa, que no aparece totalmente desnuda hasta bien entrado el siglo IV a. C. Por el contrario, el desnudo masculino era habitual en las representaciones artísticas de atletas, efebos y hoplitas, cuyos cuerpos se muestran de forma casi frontal al espectador de la imagen. Desde la perspectiva griega, el cuerpo masculino modelado en los gimnasios se hace bello también en la medida en que refleja la autodisciplina que habilitará al joven ciudadano para la defensa de su patria y para el buen gobierno del sistema político que su propio físico encarna.

Como excepción a esta norma iconográfica griega, el ámbito del hedonismo. Me refiero, sobre todo, a las numerosas escenas de banquetes legadas por la iconografía ateniense, en las que bailarinas, prostitutas y cortesanas, efebos y hombres maduros se representan de perfil, mostrando con desenfado una desnudez totalmente desprovista de halo heroico.

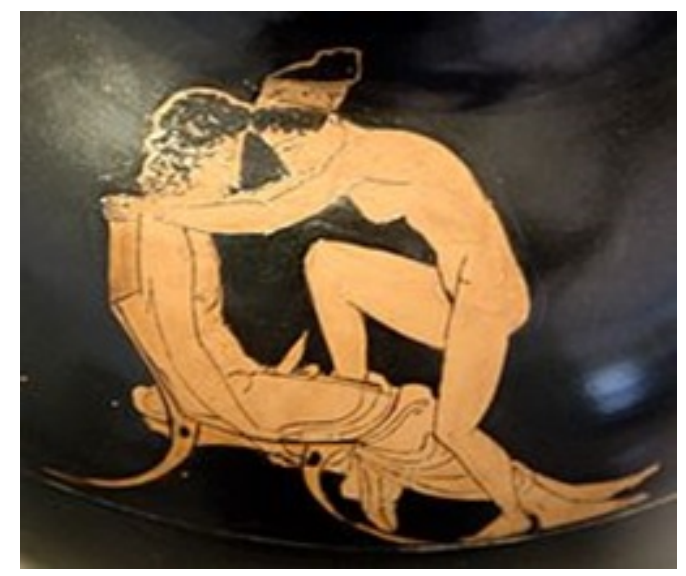

Los célebres y heroicos desnudos de guerreros esculpidos en las metopas del Partenón demuestran a la perfección que -en el ámbito de la guerra, al que nos conduce la figura de Casandra- el desnudo masculino subraya las buenas cualidades físicas, la marcada musculatura, del guerrero triunfador. Sírvanos de ejemplo una de las metopas de la fachada Sur del Partenón, elegida por la similitud entre la postura del guerrero lapita que se enfrenta al centauro y la que Casandra adopta en la pintura de Cleófrades ya presentada y que estamos a punto de retomar.

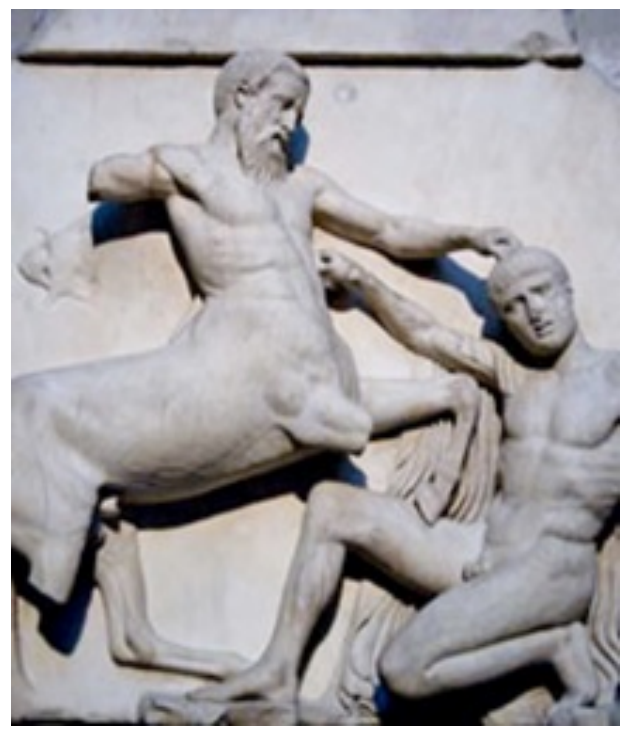

A partir de esta constatación, cabe preguntarse qué representan los raros desnudos femeninos en este ámbito bélico: ¿se trata simplemente del "signo" del acto erótico pervertido que es la violación o pueden 
estar señalando el reconocimiento como acto de valentía de las violaciones sistemáticas que, todavía hoy en día, se producen en los ámbitos bélicos? Se trata de interrogantes que no surgen espontáneamente en nuestras mentes acostumbradas a que las representaciones modernas - más concretamente, decimonónicasde Casandra tiendan a reproducir este terrible instante de su biografía que permite exhibir el estético -y pasivo- desnudo de una atractiva joven.

Como ejemplos, contemplaremos, a nuestra izquierda, la escultura de Jean-Jacques Pradier (1790-1852), conservada en el Museo Calvet de Avignon, en la que apreciamos las dimensiones mínimas que se otorgan al altar de Atenea, escondido por el cuerpo de la doncella, que da sentido al conjunto. A la derecha, el mismo desnivel de tamaño entre la Atenea diminuta a la que se acoge Casandra y el espléndido cuerpo de la heroína es reproducido por el también neoclásico Aimé Millet (1819-1891) para decorar el estanque del Jardín de Tullerías, en París.
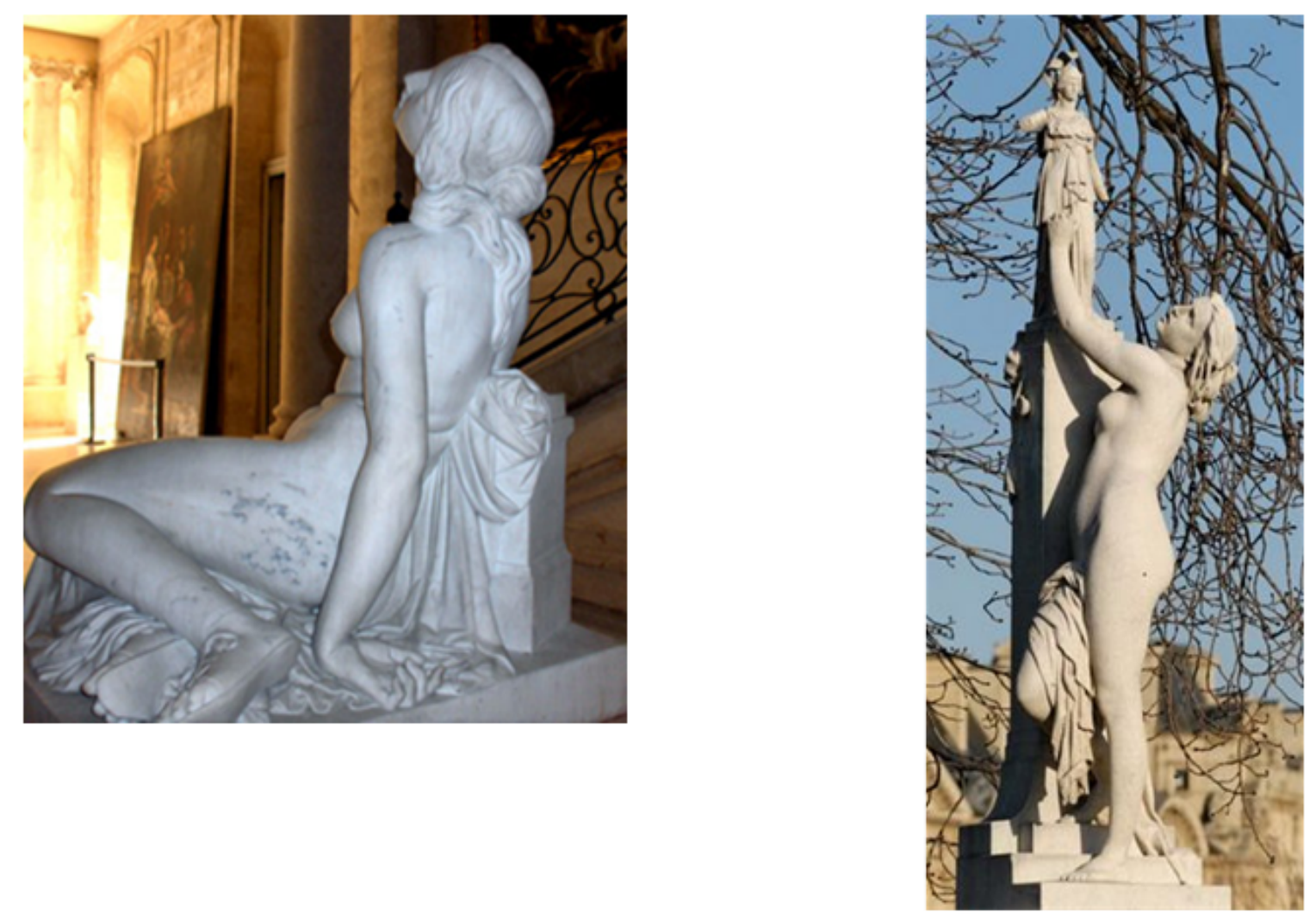

Pues bien, estos estilizados desnudos femeninos típicos de la escultura pública y de la pintura decimonónicas poco tienen que ver con la imagen del pintor Cleófrades que hemos presentado al inicio de este artículo, o sea, con la semántica de la desnudez que la iconografía ateniense de época clásica asocia a Casandra. ${ }^{6}$

En dicha imagen, el equilibrio entre el tamaño de la diosa, de la heroína y del guerrero que está a punto de atravesarla es patente. Casandra ha caído, sobre su rodilla derecha, a los pies de Atenea. Con la mano derecha le suplica al guerrero Áyax, quien la toma por la melena amenazándole con la espada. El pintor sitúa la espada a la altura del sexo de Áyax, ${ }^{7}$ como queriendo subrayar el acto al tiempo sexual e hiriente que va a llevar a cabo, como sugiriendo una equivalencia entre la violación de una mujer y la muerte de un guerrero en el campo de batalla. Con el brazo izquierdo, Casandra rodea la estatua de la diosa. Y esta la protege con su escudo sin llegar a esconder el rostro de la joven. 
Contrariamente a los desnudos de cortesanas, siempre de perfil, disimulando el sexo, el de Casandra se muestra frontal -que no de forma soez-al espectador de la vasija. Un himátion o manto anudado al cuello cae en cascada sobre la espalda de la profetisa. Este tejido enmarca la desnudez femenina como suele ocurrir en el caso de los guerreros, de tal manera que Casandra se nos revela comparable a los heroicos lapitas, los guerreros tesalios que vencieron a los centauros y cuya desnudez, enmarcada también por mantos que caen sobre los hombros, se exhibe en las metopas del Partenón, como hemos podido contemplar en la anteriormente seleccionada.

En general, la desnudez frontal de Casandra evoca sin ambigüedad la de los guerreros griegos paradigmáticos. Pero, ¿cómo relacionar el caso de la doncella violada en el templo con el del guerrero coronado por la gloria que aporta la defensa de la civilización frente a la barbarie?

Para comprender a fondo las razones de la heroica nobleza que la iconografía atribuye a Casandra, nos conviene retornar a la fuente literaria de la que habíamos partido para presentar el episodio de Áyax. Me refiero a Troyanas, estrenada en el teatro ateniense de Dioniso en el 415 a. C., o sea, más de medio siglo después de que Cleófrades plasmara la imagen comentada.

\section{Heroicas E INDEFENSAS}

El prólogo de Troyanas, en el que Atenea y Posidón decidían el tipo de retorno que depararían a los impíos griegos, da paso a un prolongado lamento de Andrómaca, que nos sitúa ya en el escenario en el que transcurrirá la obra: el campamento de cautivas troyanas que han sido sorteadas entre los jefes aqueos. Taltibio, mensajero oficial del ejército griego, es el encargado de informar sobre dicho sorteo a la reina Hécuba, quien se interesa ante todo por la suerte de sus hijas solteras: Casandra y Políxena.

En lo que se refiere a Políxena, Taltibio es incapaz de anunciarle a Hécuba en términos claros que ha sido degollada en honor de Aquiles. Así que, enigmático, afirma que a la joven "se le ha ordenado hacer servicio a la tumba de Aquiles" (Eurípides, Troyanas 264). En cuanto a Casandra, informa el mensajero, "Agamenón la ha elegido especialmente para sí” (Eurípides, Troyanas 249), noticia que estremece a Hécuba, sobre todo porque Casandra debía permanecer soltera debido a su estatus profético.

"Un segundo Áyax ha surgido para tu hija" (Eurípides, Troyanas 618-619), le comentará a Hécuba algunos versos más adelante, su nuera Andrómaca, quien pasa, inmediatamente, a anunciarle: “Tu hija Políxena ha muerto degollada junto a la tumba de Aquiles, ofrenda para un cadáver sin vida" (Eurípides, Troyanas 622-623).

La fragilidad de Casandra y Políxena las hace destacar como seres especialmente indefensos en el contexto bélico que las envuelve, de tal manera que sus destinos son regularmente comparados por quienes las rodean. Para empezar, por su propia madre, quien denuncia que sus hijas le han sido usurpadas -como Perséfone le fue usurpada a Deméter- para que protagonicen una unión en el Hades, una boda-muerte. Identificando a Casandra y Políxena al mismo tiempo como jóvenes casaderas y como niñas, Hécuba se lamenta en los siguientes términos: "Si crié a mis hijas para entregarlas a esposos de alto rango, otros, beneficiándose de ello, las arrancaron de mis brazos" (Eurípides, Troyanas 484-486). ${ }^{8}$

Ahora bien, como vamos a ver, el rasgo que verdaderamente unifica los destinos de las dos princesas orientales, educadas para ser futuras reinas, es la valentía con la que, de forma inesperada para su entorno, deciden afrontar sus destinos.

En Hécuba, la propia Políxena se identificará con esta imagen del niño brutalmente separado de la madre para explicar cómo se siente sabiendo que va a ser inmolada en la tumba de Aquiles:

A mí, retoño tuyo, cual a ternera alimentada en los montes, desgraciada yo y desgraciada tú, me contemplarás arrancada de tus manos, degollada y conducida a Hades, a las tinieblas subterráneas, donde, junto a los muertos, desdichada me hallaré. (Eurípides, Hécuba 205-210) 
Pero la joven princesa también expresa su deseo de morir, afirmando que es lo mejor que puede pasarle, en un prolongado discurso pronunciado ante la multitud del ejército aqueo, al que pone fin en los siguientes términos:

Madre, no nos pongas ningún obstáculo, ni de palabra ni de obra. Aconséjame morir antes de caer en destino vergonzoso impropio de mi dignidad. Pues quien no suele probar las desgracias, toléralas, pero le duele poner su cuello bajo el yugo. Más dichosa sería yo muriendo que viviendo, pues vivir sin dignidad [me kalôs] gran oprobio es [mégas pónos]. ${ }^{9}$ (Eurípides, Hécuba 372)

Viéndose a sí misma ante todo como hija del rey Príamo y como hermana del héroe Héctor, Políxena prefiere reunirse con ellos en el Más Allá antes que experimentar la esclavitud (Eurípides, Hécuba 349, 361 y 422). Se trata de su última decisión como ser libre (Eurípides, Hécuba 550). Una decisión que expresa con tanta firmeza como para que sus palabras sean calificadas por el griego Taltibio como "el discurso más valiente” (tlemonéstaton lógon, Eurípides, Hécuba 562). Al igual que Posidón en el Prólogo de Troyanas (Eurípides, Troyanas 40), los guerreros griegos reconocen en la actitud de Políxena una dimensión heroica de la que normalmente solo gozan los hombres muertos en el campo de batalla. Dimensión heroica que Eurípides subraya, precisamente, haciendo eco de forma explícita a la tradición artística, pues su Políxena se desnuda para aceptar voluntariamente la muerte, lo que la hace parecer una "preciosa estatua” ante el ejército que observa el sacrificio que el propio Aquiles protagoniza:

[Políxena]... cogiendo el peplo lo rompió desde lo alto de la espalda hasta la mitad del costado, junto al ombligo, mostró los senos y el pecho hermosísimo, como de estatua, y poniendo en tierra la rodilla dijo las palabras más valientes de todas: "Mira", golpea aquí, si es que deseas, oh joven, golpear mi pecho, y si quieres en la base del cuello, dispuesta está aquí mi garganta. Y él, queriendo y no queriendo por compasión a la muchacha, le corta con el hierro los pasos del aire. Salían chorros. Y ella, aun muriéndose, sin embargo, tenía mucho cuidado para caer de buena postura, ocultando lo que hay que ocultar a la mirada de los varones. ${ }^{10}$ (Eurípides, Hécuba 555-570)

Así parece evocar Eurípides la tradición pictórica que hemos ilustrado con el "radical" desnudo heroico de Casandra, al tiempo que corrige ligeramente dicha tradición, matizando con sus versos la primacía del pudor que debe presidir en el comportamiento de toda doncella respetable. A mis ojos, este texto representa un bello ejemplo de la diferencia normativa que distancia a la tradición literaria de la iconográfica, al tiempo que prueba el diálogo - por no decir "intertextualidad" - que la mente de un intelectual ateniense, como el que ahora citamos, puede establecer entre ambas.

En lo referido a Casandra, para entender su vivaz reacción cuando Taltibio hace saber que ha sido adjudicada al soberano Agamenón, hay que contar con que la joven profetisa sabe que será asesinada por Clitemnestra, la esposa de Agamenón, en cuanto ambos lleguen a Grecia. Un célebre vaso griego conocido como la Copa de Ferrara (430 a. C.) ${ }^{11}$ proporciona un testimonio detallado de este episodio evocado ya en la Odisea (11.421). Pero, en el panel de bronce de finales del VII a. C., probablemente un adorno de trípode, encontrado en el heraîon de Argos y que forma ahora parte de la colección del Museo Arqueológico Nacional de Atenas, se identifica muy bien a Casandra, más esbelta que su rival, Clitemnestra, pero totalmente dominada por esta, quien la agarra del pelo como a una víctima sacrificial, mientras alza el arma mortal, también a modo de puñal de sacrificio, con la mano derecha. 


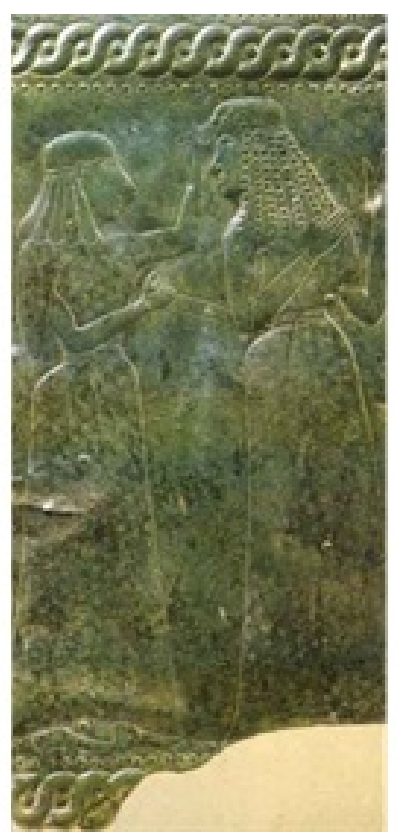

Presentándose a sí misma como causante de la muerte del destructor de su patria, Casandra definirá la suya propia como acto patriótico en un largo monólogo que se inicia como sigue:

Madre, corona mi victoriosa cabeza [nikephóron] y celebra mis bodas reales [basilikoîs gámois]. (...) Que, si existe Apolo, el ilustre Agamenón, soberano de los aqueos, va a concertar conmigo una boda más infausta que la de Helena. Voy a matarlo [ktenô], voy a destruir su casa para tomar venganza de mis hermanos y padre. (Eurípides, Troyanas 353-360)

Un monólogo al que la profetisa pone punto final retomando con fidelidad algunos elementos canónicos en los elogios fúnebres que los atenienses dedicaban a los soldados muertos por la patria:

(...) no es corona desdeñable una muerte gloriosa [kalôs olésthai] por la ciudad, mientras que hay deshonor en lo contrario. Así pues, no debes llorar, madre, por mi patria y mi boda. Para los que tú y yo más odiamos mi matrimonio será la ruina. ${ }^{12}$

(Eurípides, Troyanas 401-405)

Casandra considera su unión-muerte con el general del ejército griego como un último y definitivo enfrentamiento con el enemigo y reivindica para sí misma un estatus similar al de sus valientes hermanos muertos por la patria. El mismo estatus que le había atribuido Esquilo en el Agamenón, tragedia estrenada en 458 con la que Eurípides despliega un evidente ejercicio de intertextualidad. ${ }^{13}$

Cuando, en el Agamenón, la hija de Príamo prevé que va a morir, lo anuncia a sus interlocutores relacionando la desaparición de Troya con su propia desaparición: su patria pereció y ella caerá igualmente. ${ }^{14} \mathrm{El}$ coro, extrañado de que la joven no intente esquivar su cruel destino le pregunta: "Si de verdad conoces tu propia muerte, ipor qué, igual que una ternera impulsada por los dioses [theelátou], marchas hacia el altar con tal valentía?” (Esquilo, Agamenón 1296-1297).

Para Casandra morir es someterse al mismo destino que la ciudad de su padre. Y ante su renuncia a huir del lugar en el que sabe que le espera la muerte los ancianos de Argos le atribuyen dos prerrogativas exclusivas del hoplita: ${ }^{15}$ tener un "espíritu valiente" (eutólmou phrenós) y morir "gloriosamente" (eukleôs).

Además, en el Agamenón, la dimensión heroica de Casandra queda acentuada al ser esta asesinada con una espada, ${ }^{16}$ es decir, con el arma asociada a la muerte del guerrero. La princesa troyana y Agamenón mueren a manos de una mujer en las mismas condiciones. Sin embargo, dicho acto adquiere un significado diferente para cada uno de los dos. Para el bélico soberano Agamenón se trata de una muerte indigna, dado que, en vez de morir en el campo de batalla, ha caído en las redes ${ }^{17}$ que su propia mujer le ha tendido. ${ }^{18}$ Mientras que, como acabamos de ver, para Casandra se trata de un acto de valentía tanto por el carácter de contraataque al enemigo implícito en esta forma de morir, ${ }^{19}$ como por la lucidez con que la afronta. 


\section{FAMA inMortal de CASANDra o La PRofeta EN Wikipedia}

Las pinturas y esculturas modernas presentadas en este artículo, además del señalado grupo de obras literarias que ha protagonizado, dan una idea del poder de supervivencia de la figura de Casandra. Ahora bien, si intentamos una aproximación de Casandra a través de las imágenes privilegiadas por Wikipedia, constataremos, para empezar, que su imagen de profeta apolínea queda diluida por la magnitud de la escena de su rapto, tanto plasmada por la iconografía antigua ${ }^{20}$ como por la moderna. ${ }^{21}$

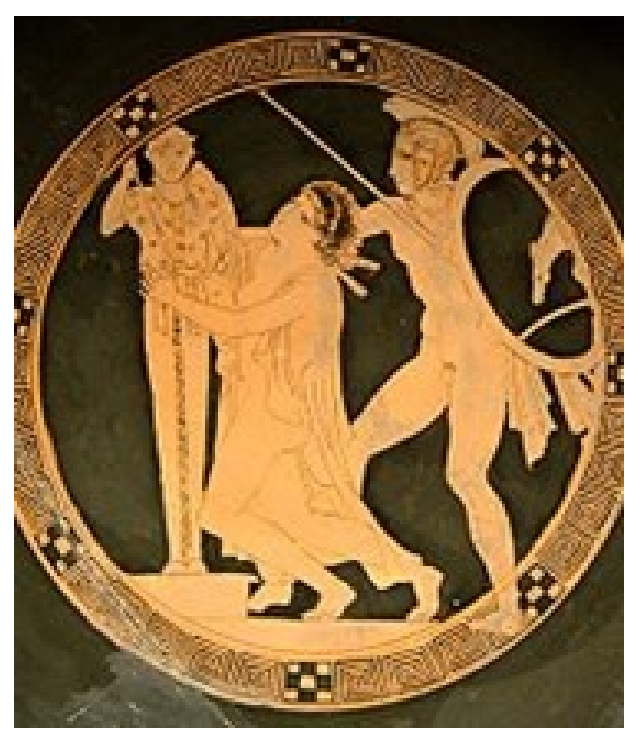

En segundo lugar, constataremos que Wikipedia evoca con certeza los rasgos báquicos de la desesperada profeta apolínea. Para este perfil de visionaria báquica, la enciclopedia se apoya en la bien anglosajona imagen propiciada por George Romney (1734-1802) en Lady Emma Hamilton, as Cassandra.

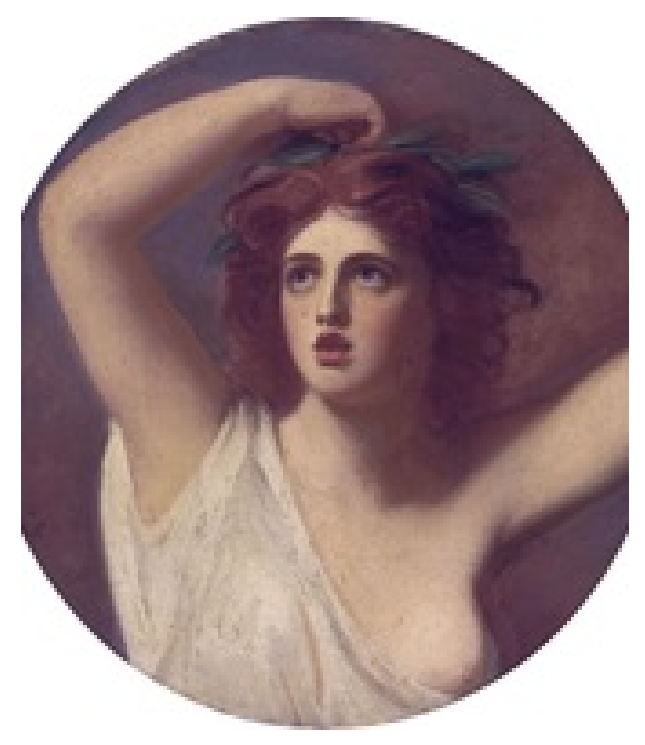

Finalmente, la identidad de nuestra figura, tan bien individualizada por los poetas y artistas griegos, se disimula hasta desaparecer bajo los rasgos de la muy institucional portavoz de Apolo que es la Sibila. 


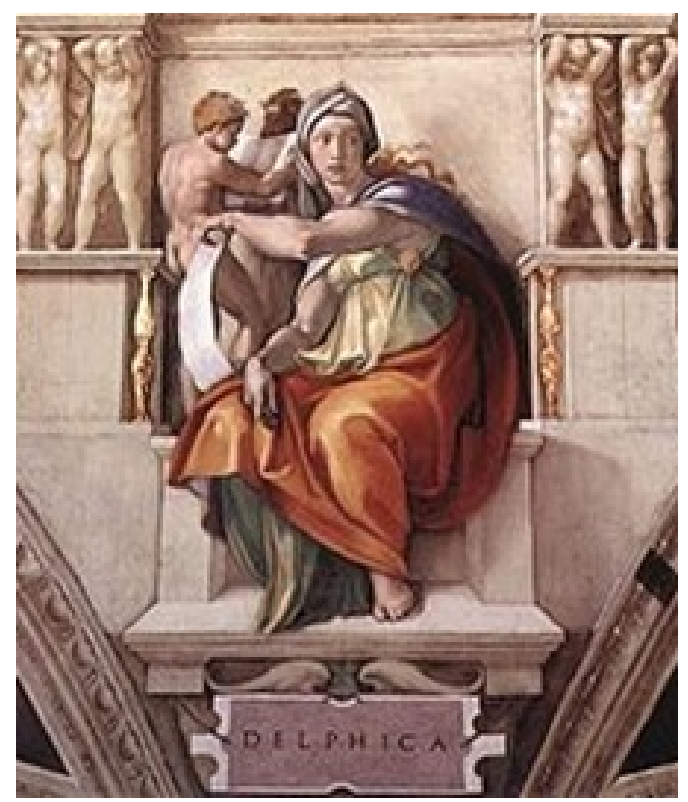

Podemos aceptar que Wikipedia reproduce la tradición artística griega de Casandra, en la medida en que insiste en su dimensión de herida heroína de guerra. Pero anula por completo su importante dimensión de concubina de Agamenón, así como la desconsolada palabra que marca su idiosincrasia.

De tal manera que, en un intento de compensar mínimamente el discurso triunfal de Wikipedia, concluyo insistiendo en la señalada lucidez de Casandra, en su consciencia de no poder escapar a su destino de mortal. Desde mi perspectiva, Casandra representa una encarnación altamente emotiva de ese "rasgo esencial de lo humano", consistente en ser capaz de imaginar la propia muerte, ${ }^{22}$ circunstancia que podría explicar, siempre en parte, el éxito discreto, pero transtemporal, de nuestra heroína.

\section{EDICIONES, COMENTARIOS Y TRADUCCIONES}

Esquilo. (1986). Agamenón (Trad. M. Pérea Morales). Madrid: ECG.

Esquilo. (1986). Coéforas (Trad. M. Pérea Morales). Madrid: ECG.

Eurípides. (1977). Hécuba (Trad. A. Medina González y J. A. López Férez). Madrid: ECG.

Eurípides. (1978). Las Troyanas (Trad. J. L. Calvo Martínez). Madrid: ECG.

Eurípides. (1992). Tragedias troyanas (Trad. M. Fernández-Galiano, versión rítmica). Barcelona: RBA Editores.

Licofrón. (1956). Alejandra (Trad. L. Mascialino). Madrid: Ediciones Alma Mater.

Mazon, P. (Ed.). (1972). Eschyle: Agamemnon. Paris: Les Belles Lettres.

Mazon, P. (Ed.). (1972). Eschyle: Choéphores. Paris: Les Belles Lettres.

Méridier, L. (Ed.). (1973). Euripide: Hécube. Paris: Les belles lettres.

Parmentier, L. (Ed.). (1968). Euripide: Les Troyennes. Paris: Les belles Lettres.

\section{REFERENCIAS}

Cohen, B. (1993). The anatomy of Kassandra' Rape: Female Nudity Comes of Age in Greek Art. Source, 12(2), 37-46. Davreux, J. (1942). La légende de la prophétesse Cassandre d'après les textes et les monuments. Liège: Librairie E. Droz.

Frontisi, F. \& Lissarrague, F. (2001). Corps féminin, corps virginal: images grecques. En L. Bruit-Zaidman (Ed.), Le corps des jeunes filles de l'antiquité à nos jours (pp. 59-60). Paris: Perrin. 
Gómez Pin, V. (2 de febrero de 2012). El mal gratuito infringido a Tony Nicklinson [El Boomeran. Blog literario en español]. Recuperado de http://www.elboomeran.com/blog-post/6/11841/victor-gomez-pin/el-mal-gratuito-i nfringido-a-tony-nicklinson/

Grimal, P. (2004). Diccionario de Mitología griega y romana. Buenos Aires: Paidós.

Iriarte, A. (1990). Las redes del enigma. Voces femeninas en el pensamiento griego. Madrid: Taurus.

Iriarte, A. (1994). Cassandra trágica. En M. Jufresa (Ed.), Saviesa i perversitat: les dones a la Grécia Antiga (pp. 47-82). Barcelona: Destino.

Iriarte, A. (1999). Le chant interdit de la clairvoyance. En M. Goudot (Ed.), Cassandre (pp. 42-64). Paris: Éditions Autrement.

Iriarte, A. (2003). El ciudadano al desnudo y los seres encubiertos en la antigua Grecia. Veleia, 20, 273-296.

Iriarte, A. (2006). La guerra, Casandra y Christa Wolf. En J. V. Bañuls, F. De Martino y C. Morenilla (Eds.), El teatro greco-latino y su recepción en la tradición occidental (pp. 256-267). Bari-Valencia: Levante Editori.

Iriarte, A. (2007). Le tiessage de la nudité. En V. Sebillotte \& N. Ernoult (Dirs.), Problèmes du genre en Grèce ancienne (pp. 289-302). Paris: Publications de la Sorbonne.

Iriarte, A. (2010). Cassandre: une bacchante apollinienne. Arxaiologia \& Téxnes, 35-40.

Iriarte, A. (2012). Oradora y bacante apolínea: polisémica Casandra. En F. de Martino y C. Morenilla (Eds.), Teatro y sociedad en la Antigüedad clásica. El logos femenino en el teatro (pp. 151-162). Bari: Levante Editori.

Iriarte, A y González, M. (Eds.). (2008). Entre Ares y Afrodita. Violencia del erotismo y erótica de la violencia en la Grecia antigua. Madrid: Abada.

Lessing, D. (2002). El viento se llevará nuestras palabras. Un testimonio comprometido sobre la destrucción de Afganistán (Trad. J. Arconada Rodríguez). Barcelona: B Ediciones.

Loraux, N. (1985). Façons tragiques de tuer une femme. Paris: Hachette.

Mazzoldi, S. (2001). Cassandra, la vergine e l'indovina. Identità di un personaggio da Omero all'Ellenismo. Pisa-Roma: Istituti Editoriali e Poligrafici Internazionali.

Rodríguez Cidre, E. (2010). Cautivas Troyanas. El mundo femenino fragmentado en las tragedias griegas. Córdoba: Ediciones Del Copista.

\section{Notas}

* Ana Iriarte es Catedrática de Historia Antigua en la Universidad del País Vasco (España). Doctora por la ÉHÉSS de París, obtuvo la beca de la DGRST francesa, así como las becas Predoctoral y Post-doctoral del Gobierno Vasco. Ha sido profesora invitada en la Sorbona y el ÉHÉSS de París, en la Universidad de Buenos Aires, la Federal de Río de Janeiro, la Autónoma de México y la Jean Jaurés de Toulouse. Entre sus libros se destacan: Las redes del enigma (1990), Democracia y tragedia (1997), De amazonas a ciudadanos (2002) e Historiografia y mundo griego (2011).

1 La bibliografía sobre esta figura es extensa. Como trabajos de referencia: Davreux (1942), Mazzoldi (2001), Goudot (1999). Las páginas 42-64 de este volumen recogen, bajo el título "Le chant interdit de la clairvoyance" la mayoría de las conclusiones del inédito Diplôme de l'ÉHESS que, bajo la dirección de N. Loraux, dediqué a Cassandre dans la tradition littéraire grecque (1980). Sobre la experiencia de este aprendizaje al hilo de Casandra me extiendo en "Descifrando enigmas con Nicole Loraux" (2006, pp. 41-56). Por supuesto, Casandra es una figura presente también en mi Tesis Doctoral, traducida al castellano y publicada como Las redes del enigma. Voces femeninas en el pensamiento griego (1990). Asimismo, he estudiado la figura de Casandra desde los diferentes ángulos que señalan los siguientes títulos: "Cassandra trágica” (1994, pp. 47-82); "La guerra, Casandra y Christa Wolf” (2006, pp. 256-267).

2 Desde la perspectiva iconográfica, estudié la figura en cuestión en el capítulo "Casandra Bélica" (2008, pp. 216-268). En las últimas publicaciones sobre la profeta, destaqué su dimensión dionisíaca: "Cassandre: une bacchante apollinienne" (2010, pp. 35-40); "Oradora y bacante apolínea: polisémica Casandra” (2012, pp. 151-162).

3 Esquilo, Agamenón, por ejemplo, 1172.

4 Las traducciones presentadas en el artículo no siguen textualmente las ediciones citadas en la bibliografía, sino que se han revisado en aras de mayor precisión de la exposición. También se han consultado los textos y propuestas de traducción al inglés para las obras aquí citadas de la colección de autores clásicos disponible en Perseus Digital Library. 
5 Como tuve ocasión de demostrar en mi artículo "El ciudadano al desnudo y los seres encubiertos en la antigua Grecia” (2003, pp. 273-296). Una tesis que afiné más tarde en "Le tiessage de la nudité" (2007, pp. 289-302).

6 El primer corpus de escenas de la violación de Casandra en la cerámica ateniense lo elaboró Juliette Davreux (1942) en su libro La légende de la prophétesse Cassandre d'après les textes et les monuments. Para el enfoque que subrayo en este momento, véase Cohen (1993).

7 Como lo hacen Frontisi \& Lissarrague (2001, pp. 59-60). No compartimos, sin embargo, con estos autores la idea de la simple incongruencia de la exhibición frontal del sexo de Casandra, como vamos a explicar ahora mismo.

8 Cf. ibid. 513. Para la animalización metafórica de las doncellas sacrificadas como evocación del matrimonio, en el que, al igual que la víctima, la joven es sumisa, pasiva, entregada y conducida, véase Loraux (1985, pp. 65-68).

9 Cf. ibid. 214-215. Para la subversión del ritual sacrificial que supone el que la víctima acepte su propia muerte como "una decisión propia" y para el tema de los valores femeninos en Eurípides, véase la cuidada tesis de Elsa Rodríguez Cidre (2010) Cautivas Troyanas. El mundo femenino fragmentado en las tragedias griegas.

10 En los términos exactos de la traducción de BCG.

11 Copa ática de figuras rojas, ca. 430 a. C. Museo arqueológico de Ferrara.

12 Cf. ibid. 457-461 para el carácter victorioso de la acción de Casandra.

13 Iriarte (1994, pp. 54 y ss.).

14 Esquilo, Agamenón 1171-72. Cf. ibid. 1160.

15 Esquilo, Agamenón 1302 y 1304.

16 Esquilo, Agamenón 1149. Cf. ibid. 1528 y Esquilo, Coéforas 1011. En Troyanas $361 \mathrm{el}$ arma reservada a Casandra es el hacha.

17 Esquilo, Agamenón 1382-83. Cf. Licofrón, Alejandra 1099-1102.

18 Esquilo, Coéforas 479-480.

19 Esquilo, Agamenón 1279.

20 Entre las posibilidades que brinda la cerámica de figuras rojas, Wikipedia selecciona una bella copa fechada entre el 430 y el 420 a. C.

21 El impactante y algo tétrico cuadro de Solomon Joseph Solomon (1886), Ajax et Cassandre, es el privilegiado por la citada fuente de Internet para evocar el impacto que el episodio de la violación de la princesa troyana tiene en época moderna.

22 Vuelvo a pensar aquí en el texto citado como encabezamiento de la presente reflexión sobre Casandra: Gómez Pin (2012). 